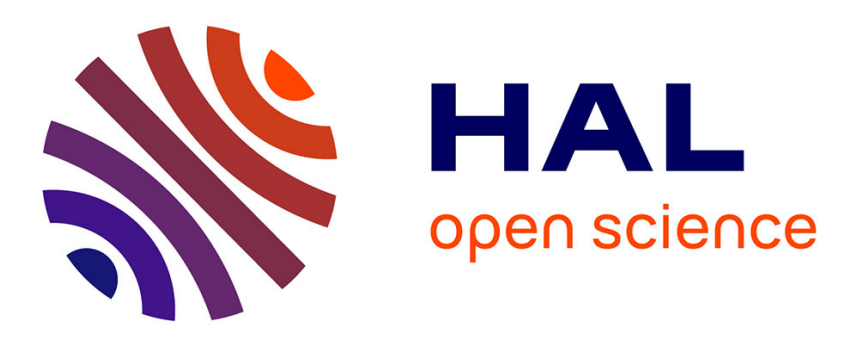

\title{
Colour-blind diversity: how the "Diversity Label" reshaped anti-discrimination policies in three French local governments
}

Laure Bereni, Renaud Epstein, Manon Torres

\section{- To cite this version:}

Laure Bereni, Renaud Epstein, Manon Torres. Colour-blind diversity: how the "Diversity Label" reshaped anti-discrimination policies in three French local governments. Ethnic and Racial Studies, 2020, Diversity in local political practice, 43 (11), pp.1942-1960. 10.1080/01419870.2020.1738523 . halshs-02735300

\author{
HAL Id: halshs-02735300 \\ https://shs.hal.science/halshs-02735300
}

Submitted on 24 Jul 2020

HAL is a multi-disciplinary open access archive for the deposit and dissemination of scientific research documents, whether they are published or not. The documents may come from teaching and research institutions in France or abroad, or from public or private research centers.
L'archive ouverte pluridisciplinaire HAL, est destinée au dépôt et à la diffusion de documents scientifiques de niveau recherche, publiés ou non, émanant des établissements d'enseignement et de recherche français ou étrangers, des laboratoires publics ou privés. 


\title{
Colour-blind diversity: how the 'Diversity Label’ reshaped anti- discrimination policies in three French local governments
}

\author{
Laure Berenia1, Renaud Epstein ${ }^{\mathrm{b} 2}$ and Marion Torres ${ }^{\mathrm{c} 3}$ \\ a CNRS -Centre Maurice Halbwachs, Paris, France \\ b Sciences Po Saint-Germain - CESDIP, Saint-Germain-en-Laye, France \\ c INED -Centre Maurice Halbwachs, Paris, France
}

Ethnic and Racial Studies, published online 09 mars 2020.

https://doi-org.inshs.bib.cnrs.fr/10.1080/01419870.2020.1738523

\begin{abstract}
Drawing on the qualitative study of three French local governments (Paris, Nantes and the Seine-Saint-Denis department), this article examines the implementation of local antidiscrimination policy during the 2010s. To what extent have these local governments, particularly eager to assert "diversity" values, renegotiated the dominant, colour-blind perspective prevailing at the national level? To address this question, we examined how they used a policy instrument called the 'Diversity Label'. We found that in the three cases, the commitment to the label reinforced both the institutionalization and the managerialization of anti-discrimination policy. Yet, in Nantes and Paris, it also led to a deracialization of anti-discrimination policy - i.e. to the obliteration of its ethno-racial dimension. The Seine-Saint-Denis department, where the majority group tends to become a minority, appears as a contrasting case, as ethno-racial concerns have remained central.
\end{abstract}

\footnotetext{
1 Laure Bereni : laure.bereni@cnrs.fr

2 Renaud Epstein : renaud.epstein@sciencespo-saintgermainenlaye.fr, Twitter @renaud_epstein

3 Manon Torres : manon.torres@ined.fr
} 
This study reveals the unlikely conditions under which French local governments differ from national colour-blindness.

ARTICLE HISTORY Received 0607 2019; Accepted 17022020

\section{KEYWORDS}

Diversity, France, anti-discrimination policy, colour-blindness, local government, certification label

Compared to other countries of immigration that have embraced multiculturalism and/or race-conscious anti-discrimination policies, France has been studied as an emblematic case of colour-blindness (Favell 1998, Bleich 2000, Mazouz 2017, Sala Pala 2010)ํ․ This perspective, strongly ingrained in the ideology of "republican universalism", finds its legal roots in Article 1 of the 1958 French Constitution: the Republic "guarantees equality before the law for all citizens, regardless of descent, race, or religion", and has been endorsed by the leading anti-racist organizations since the early 1970s (Bleich 2000, Lamont, Morning, Mooney 2002). Colour-blindness informs four dimensions of French public discourse and public policy toward ethno-racial minorities. Firstly, it pervades an assimilationist perspective on immigration, in which immigrants and their descendants are expected to integrate into the cultural values and behaviours of the majority, or at least to confine their cultural specificities to the private sphere (Schnapper 1998). Secondly, colour-blindness manifests itself in the reluctance to recognize ethno-racial discrimination as a distinct social problem -what D. Fassin and E. Fassin (2006) refer to as a "denial". Since the end of the 1970s, postcolonial immigrants and their descendants have remained mostly 
addressed through the well-established paradigms of integration, social insertion and urban cohesion (Kirszbaum 2004, Dikec 2007, Mazouz 2017, Cerrato Debenedetti 2018, Escafré-Dublet and Lelévrier 2019). Thirdly, colour-blindness translates into the legal restrictions on the collection of ethnic and racial statistics, a subject that has repeatedly triggered heated controversies since the late 1990s (Peer and Sabbagh 2008, Simon 2008). Finally, the republican ideology of colour-blindness results in the absence of any form of positive action explicitly based on ethno-racial grounds, although preferential treatments based on other grounds, notably gender and place of residence, have gained legitimacy since the yearly 2000s in the political and employment fields (Calvès 2016).

Yet, the principles of republican universalism have encountered numerous challenges in the last twenty years. Firstly, in France like in other European countries, under the pressure of EU 2000 anti-discrimination directives, a more extensive and protective legal anti-discrimination framework has been established since the early 2000s. Secondly, by the second half of the decade, France has witnessed the development of a discourse celebrating the benefits of diversity, especially in the workforce, echoing a globalized diversity discourse born in the U.S. in the 1980s (Kelly and Dobbin 1998, Bereni 2009). The "promotion of diversity" was initially brought to the public agenda by business elites, through the introduction of a "Diversity Charter" (Charte de la diversité) (2004) asserting a corporate commitment "in favour of ethnic, cultural, and social diversity within [their] organization"2. This diversity framing was quickly adopted by the national government, as illustrated by the creation in 2008 of the state-monitored "Diversity Label" (label diversité), a public award granted to private and public employers that develop "good practices" with regard to "the prevention of discrimination and the promotion of diversity", primarily in 
their management of human resources (HR). Thirdly, policy orientations and instruments set up at the national level within the framework of the republican principles have not systematically been replicated identically at the local level. Studies conducted in various European countries found that national frames of reference regarding diversity and equality of treatment can be reshaped by urban governments (Poppelaars and Scholten 2008, Dekker and al. 2015, Schiller 2015), and this was the case in France (Flamant, 2017, Meziani-Remichi and Maussen 2017, Cerrato Debenedetti 2018, Martínez-Ariño and al. 2018). In particular, while the issue of combating ethno-racial discrimination faded away from the national agenda in the late 2000s, the picture was different at the local level. Against a background of hardening public attitudes towards immigrants and their descendants under the right-wing presidency of Nicolas Sarkozy (2007-2012), this issue gained some prominence on the local political agendas especially in large cities governed by centre-left coalitions (Martínez-Ariño and al. 2018).

This article examines the implementation of anti-discrimination policy by French local governments during the 2010s. In a country dominated by a colour-blind doctrine and in the context of the weakening of this policy at the national level, to what extent have local governments, and more particularly those eager to assert "diversity" values, renegotiated the dominant national perspective on ethnic and racial issues?

To address this question, we explored how three local governments used a specific public policy instrument, the Diversity Label. Launched in 2008 by the French government, the label quickly became a pillar of the national anti-discrimination policy in employment, albeit of modest scope. At the end of 2019, more than a decade after its creation, 108 large organizations were label holders, including 33 public bodies. At this date, the label covered 
around 500,000 public sector employees ${ }^{3}$. Seeking to boost the diffusion of the label in the public sector from the start of the 2010s, the French state encouraged local government bodies $^{4}$ to adopt it, with relatively little success. By the end of 2019, only 6 local governments ( 5 cities and 1 department) had received the Diversity Label- including Nantes (2012), Conseil départemental de Seine-Saint-Denis (2016) and Paris (2019)5_ while a few others were considering applying for it.

The article investigates three cases of local governments, which were considered, when fieldwork was conducted (2013-2019), as particularly advanced in terms of antidiscrimination policies: Nantes and the Seine-Saint-Denis department, both label holders, and Paris, which was in the last stages of the label application process in 2018-2019. Did the Diversity Label act as a lever for addressing ethno-racial discrimination and shifting away from the national colour-blind framework at the local government scale?

In the three cases, we found that the Diversity Label led to the institutionalization of antidiscrimination policies, and simultaneously reinforced the managerialization of these policies (Dobbin 2009, Edelman 2016): while local anti-discrimination programs had been so far directed towards external targets (local communities, civic organizations and firms), the label led to an increasing focus on internal, organizational processes, with a growing influence of HR management ideas. Yet, the cases differ in terms of how race and ethnicity were addressed. In Nantes and Paris, the commitment to the Diversity Label led to a deracialization of anti-discrimination and diversity policies - that is, to the obliteration of their specifically ethno-racial dimension (Doytcheva 2015) -, in line with a broader national pattern. The Seine-Saint-Denis department appears as a contrasting, exceptional case. In this highly segregated suburban space, where the majority group tends to become a 
minority - 50 per cent of minors are of foreign descent (Beauchemin and al. 2018) - ethnoracial concerns remained at the core of anti-discrimination policy. Studying this contrasting case reveals the unlikely conditions for French local governments to address straightforwardly ethno-racial issues in their diversity policies.

\section{Genesis and development of a multilevel anti-discrimination policy}

\section{National level}

Despite the rising presence of postcolonial immigrants and their descendants since the $1960 s^{6}$, the existence of ethno-racial discrimination was recognised belatedly and precariously in France (Heargraves 2015, Mazouz 2017). In the aftermath of the $2000 \mathrm{EU}$ anti-discrimination directives, the rules on the burden of proof were adjusted to be more favourable to plaintiffs, the list of legal discrimination grounds was progressively expanded (to 25 at the time of writing), and an independent agency ${ }^{7}$ was created to facilitate the enforcement of anti-discrimination rights (Chappe 2011). The EQUAL Program, launched by the EU in 2000, provided a framework and financial support for the emergence of "experimental" anti-discrimination initiatives. involving public and private, local and national actors. Several of these plans targeted ethno-racial discrimination specifically (Cerrato Debenedetti 2018).

At the same time, the diversity discourse, introduced by business circles, gained prominence in the public debate. It initially appeared as an attempt to shift away from the colour-blind republican paradigm, and to put the issue of ethno-racial minorities (called "visible minorities") at the core of public attention (Bereni 2009, Doytcheva 2015). 
The riots that engulfed hundreds of relegated suburban neighbourhoods in November 2005 completed the process of bringing the issue of ethno-racial discrimination on to the national agenda. In March 2006, the "Equal opportunity" law (Egalité des chances) was presented as a response to the discriminations that affected the people living in those neighbourhoods and implicitly targeted young people of postcolonial descent.

Yet, by the end of the 2000s, the issue of ethno-racial discrimination lost importance on the national agenda (Simon 2015). The traditional paradigms of integration, social insertion and urban cohesion regained the upper hand (Safi 2017, Cerrato Debenedetti 2018). In the workplace, "anti-discrimination" and "diversity" policies became increasingly detached from the ethno-racial significations that pervaded their initial formulations (Mazouz 2017, Doytcheva 2015). On the one hand, these policies referred to an individual-approach to equal treatment - a "liberal" (as opposed to structural) conception of anti-discrimination (Stryker 2001). On the other hand, they increasingly targeted other disadvantaged groups, such as women, disabled or senior workers, rather than ethnic and racial minorities.

\section{Local level}

The decline of national policies targeting ethno-racial minorities at the turn of the 2010s was partly counterbalanced by the development of such policies at the local level, especially in the largest and most diverse cities (Cerrato Debenedetti 2018). Local governments' attention to immigrants and their descendants was hardly new. A number of initiatives had been carried out by municipalities during the 1980s and 1990s to manage the "reception" and "integration" of immigrants, promote "intercultural dialogue", or support area-based "social development programs" in deprived neighbourhoods, where 
post-colonial immigrants and their descendants were concentrated (Kirszbaum 2004, Dikec 2007, Downing 2016). By the early 2000s, the local implementers of these policies were increasingly encouraged by the French government and European institutions to take the anti-discrimination legal framework into account, which they did by integrating it into existing urban policy and integration programs (Kirszbaum 2004, Flamant 2017). The 2008 municipal election campaign witnessed an unprecedented politicization of the issue of the "diversity" of the lists of candidates (Avanza 2010). In many big cities and suburban municipalities, socialist party candidates highlighted the issues of discrimination and diversity to show their opposition to Nicolas Sarkozy, who had adopted the National Front's themes during the 2007 presidential campaign and, once elected, gave priority to asserting "national identity" that was deemed to be threatened by immigration. In the immediate aftermath of the 2008 municipal elections, which saw centre-left coalitions triumph in more than two-thirds of municipalities with more than 100,000 inhabitants, deputy mayors and policy officers were appointed to "fight against discrimination" in many of these cities ${ }^{8}$. By 2008, anti-discrimination officers in several municipalities held training sessions on discrimination for a variety of local professionals, launched awareness-raising campaigns, put structures to provide legal support in place, and so forth.

All of these local policies targeting ethno-racial minorities shared some common features with the national, republican framing: they addressed their targets only implicitly and indirectly, relying on proxies such as place of residence, immigrant background, social deprivation. Besides, officers in charge of anti-discrimination policies remained relatively marginal within the local administrations, their initiatives remaining mainly symbolic and 
decoupled from organizational routines. Yet, at the turn of the 2010s, in the context of a declining concern for ethno-racial issues at the national level, local governments - more particularly large cities - asserted themselves as major promoters of antidiscrimination policies, primarily focusing on post-colonial immigrants and their descendants. Against a background of cities acquiring increasing autonomy from the state (Le Gales 2011, Epstein 2013), the commitment of some mayors and urban governments to fighting discrimination supported the hypothesis that national colour-blindness could be inflected at a local level.

\section{Case selection and methods}

\section{The Diversity Label}

In order to test this hypothesis, we examined the implementation of the Diversity Label in three local governments. The introduction of such a label reflects a broader evolution of French regulatory framework, which has increasingly involved non-state actors in the design and implementation of public policies (Bergeron and al. 2014,). Introduced by the French state in 2008, the label rewards employers demonstrating "good practices" with regard to the "prevention of discrimination and promotion of diversity", mostly in RH processes. Applicants are subject to a "quality management audit" by an independent certification body (AFNOR, French Standardization Association) which checks, on site, their "compliance" with the label's specifications. To receive the label, applicants must set up an diagnosis of their major "discrimination risks", carry out an assessment of their HR procedures, implement staff training and awareness sessions with regard to discrimination, set up an "internal" (targeting employees) and "external" (targeting the 
local communities) communication policy, and establish an internal grievance procedure. The final decision of awarding the label is made by a "National Diversity Label commission", composed of representatives of the State, labour unions, employers' organisations, and human resources experts. The label is delivered for 4 years, renewable, with an on-site audit by the AFNOR every two years. This soft policy instrument, based on the voluntary participation of applicants, has become one of the main policy tools for fighting discrimination in the workplace since the end of the 2000s (Bereni and Epstein 2015). While the Diversity Label has often been branded as rewarding organizations that go "beyond" legal requirements, it essentially leads organizations to signal their compliance with the non-discrimination legal framework. The Diversity Label does not impose any monitoring or affirmative action programs. Recipients are held by an obligation of means (setting up management procedures), rather than outcomes (redressing inequalities).

Although the Diversity Label was originally designed for large private sector companies, this instrument was quickly promoted among public sector employers. Keen to be seen as an exemplary and modern employer, in the context of bureaucratic reforms inspired by New Public Management (Bezes 2017), the French government committed several major ministries to applying for the label, and repeatedly incentivized local governments to adopt it. For multiple reasons - political, financial, technical, etc. (Bereni and Epstein 2015) - and despite the incentives, the label met with less success in local governments than in national-government bodies. 


\section{Data and methods}

In order to explore if and how the Diversity Label reshaped local anti-discrimination policies, we investigated 13 local governments from 2013 to 2018. The article draws on data from two distinct qualitative studies. Laure Bereni and Renaud Epstein conducted the first study in 2013-2014 (Bereni and Epstein 2015). It mostly consisted of 18 interviews with officers and elected officials in Nantes (one of the few holders of the Diversity Label at the time), and 12 interviews with anti-discrimination officers working in 11 other local governments (including Seine-Saint-Denis). A corpus of internal documents was collected in each local government. Three interviews updating the study were held in 2018 with professionals in charge of anti-discrimination policies in Nantes and Seine-Saint-Denis, which by then had been awarded the label. Second, the article also draws on an in-depth, ethnographic study of Paris application for the Diversity Label, carried out by Manon Torres since 2017, based on participant observation over more than a year within municipal departments, and on 10 interviews with various actors engaged in implementing these policies. The 43 interviews that make up the corpus were fully transcribed and analysed inductively.

\section{Case studies: Nantes, Paris, Seine-Saint-Denis}

The three local governments selected for the case studies differ in several ways. Firstly, compared to Paris or to the Seine-Saint-Denis department that count respectively 2.1 and 1.6 million inhabitants, Nantes is a medium-sized city (the 6th largest in France, with 300000 inhabitants). Secondly, the three local governments do not have the same legal competencies. The Seine-Saint-Denis department is in charge of social and health welfare 
for families, the elderly, the disabled, as well as secondary schools. As all municipalities, Nantes has a wider range of competencies including urban planning, housing, transportation, social support for families and youth, primary education, culture and sport. The city of Paris is both a municipality and a department, with a single council - a unique case in France -, and is granted both municipal and departmental competencies. Thirdly, regarding public policies and public service innovations, Paris and Nantes are frequently recognized as "trendsetting cities" (Bereni and Epstein 2015); their governments' initiatives are held up as examples to follow at the national or European level, in areas as varied as sustainable development, urban regeneration, technological innovation or culture. Conversely, the Seine-Saint-Denis department is rarely praised as a model. It suffers from a poor reputation nationwide, as it has become a symbol in recent years of France's troubled suburbs.

Yet, these three local governments have shared features: they are ruled by center-left coalitions (led by Socialist Party representatives); and they clearly state their commitment to the values of diversity, cosmopolitism, reception of foreigners, and equal opportunity. In Nantes and Paris, the Diversity Label crowned already established anti-discrimination initiatives. With respect to ethno-racial diversity, which can only be measured approximately because of the lack of ethno-racial data, the three territories have a presence of immigrants and people of foreign descent (notably from non-European countries) at least equal to the national average, although this share highly varies among the three cases: the proportion of immigrants in Nantes is just above the national average, while it is twice the national average in Paris, and three times the national average in the Seine-Saint-Denis department(see Table 1). 
Compared to other large French cities, Nantes experienced a quite recent wave of postcolonial immigration. At the 1999 census Nantes's immigrants made up only 3.6 per cent of its population. Seventeen years later, it had almost caught up with the national average, with 9.6 per cent of immigrants (84 percent of whom were born outside Europe). These are concentrated in the city's social housing neighbourhoods, where the proportion of immigrants in the population ranges from 22 per cent to 32 per cent for the most deprived of these neighbourhoods. While immigration is a recent phenomenon in Nantes, it echoes its slave-trading history, which has become the subject of local commemorative policies culminating with the opening of a Slavery abolition memorial in the early 2010s. Paris has long been a city of immigration. Its population comprises 14.4 per cent foreigners and 20.3 per cent immigrants (of whom 75.8 per cent were born outside Europe). The city's mayor elected in 2014 is the daughter of European immigrants, who regularly reminds people that she was granted French citizenship only as a teenager. In the month following her election, she instructed the deputy mayor in charge of "gender equality and the fight against discrimination" to draw up a "comprehensive plan to combat discrimination", which implied among other things to apply for the Diversity Label. At the time the research was being conducted (2017-2019), Paris was about to submit its application for the Diversity Label, as well as for the equality Label, another government certification label which focuses more specifically on workplace equality between women and men ${ }^{9}$.

The Seine-Saint-Denis department not only differs from Nantes and Paris in terms of legal status, but also from a socio-spatial standpoint: located on the outskirts of Paris, it is the 
poorest metropolitan department, with the largest number of deprived neighbourhoods where populations with an immigrant background are concentrated. 40 per cent of the department's inhabitants live in an area targeted by urban policy initiatives, six times more than the national average. The population of the department comprises 23.6 per cent foreigners, 30 per cent immigrants (of whom 84.3 per cent are from outside Europe), and a significant proportion of immigrants' descendants (28 per cent of adults aged 18 to 50 , and 50 per cent of under-18s) (INSEE 2015, Beauchemin and al. 2018). The Seine-Saint-Denis department is an untypical case regarding the presence of ethno-racial minorities. It is, moreover, routinely racialized in French public and media discourse, e.g. primarily described as an area of immigrants and people of colour, and often stigmatized as such.

Table 1: Proportion of foreigners, immigrants, and non-EU immigrants (2016 Census)

\begin{tabular}{|c|c|c|c|}
\hline & Foreigners & Immigrants & $\begin{array}{l}\text { Non-EU } \\
\text { immigrants }\end{array}$ \\
\hline France & $6.7 \%$ & $9.4 \%$ & $6.5 \%$ \\
\hline Nantes & $7.6 \%$ & $9.6 \%$ & $8.1 \%$ \\
\hline Paris & $14.4 \%$ & $20.3 \%$ & $15,4 \%$ \\
\hline $\begin{array}{l}\text { Seine-Saint- } \\
\text { Denis }\end{array}$ & $23.6 \%$ & $30.0 \%$ & $25.3 \%$ \\
\hline
\end{tabular}




\section{Institutionalization and deracialization of diversity policies: Nantes and Paris}

In the two cities, the Diversity Label led, on the one hand, to the institutionalization and managerialization of pre-existing anti-discrimination policies. On the other hand, it resulted in a process of deracialization of these policies.

\section{Institutionalization and managerialization}

Since the Socialist Party took over the town hall in 1989, Nantes has been strongly committed to the fight against racism, the integration of immigrants, and the social development of neighbourhoods where these are concentrated. However, it was only following the suburban riots of November 2005 that the issue of discrimination made it to the local political agenda. In the following months, at the instigation of its socialist mayor, Jean-Marc Ayrault, one of the country's leading opposition figures, and after having put in place a "benchmark for local policies for fighting discrimination in Europe", the city implemented an anti-discrimination policy comprising both "external" (targeting the territory) and "internal" (targeting city employees) components. The former was entrusted to a deputy mayor and an "integration" policy officer, both with an activist background, who occupied marginal positions in the municipality and had only a limited budget at their disposal. As a result, the external component was operationalized only to a limited extent, which consisted essentially of actions to raise public awareness. The policy's internal component was entrusted to a policy officer who was attached to the HR department, but worked closely with her colleagues in charge of the external component. This resulted in the setting up of an internal diagnostic process; the signing of a "Charter for Diversity and Gender Balance in the Workplace", which symbolically marked the municipality's 
commitment in this regard; the creation of an internal grievance procedure; and the formation of an "internal consultative committee for diversity and gender balance", which brought together officers from different departments, union representatives, and elected representatives.

The anti-discrimination policy gained new momentum in January 2011, when the mayor announced his decision to apply for the Diversity Label and obtain it by the end of the year. The mayor's commitment produced an unprecedented mobilization of the municipal bureaucracy around the theme of discrimination and diversity under the guidance of a HR department whose leadership had been reshaped and reaffirmed. Unlike their predecessors, the new HR leaders, imbued with New Public Management ideas, firmly made the case for setting up an anti-discrimination policy. They saw the Diversity Label as a tool to centralize and formalize HR management procedures that, until then, had been largely informal, decentralized, and influenced by political patronage. Applying for the label thus made it possible to establish more transparent processes, reducing the risks of workplace discrimination, while at the same time giving HR officers the opportunity to extend their jurisdiction (Abbott 1998) within the administration. Nantes's involvement in the Diversity Label resulted in an anti-discrimination policy increasingly focused on managerial issues within the Nantes administration, separated from and to the detriment of external actions targeting local stakeholders (businesses, schools, cultural and sport clubs, NGOs, etc.).

In Paris, the Diversity Label also resulted in the institutionalization and managerialization of pre-existing anti-discrimination programs. The city had put in place a unit dedicated to 
promoting gender equality in the early 2000s, and had appointed an anti-discrimination officer, mostly concerned with ethno-racial discrimination, by the late 2000s. Following the 2014 municipal election, the Diversity Label project was first entrusted to the deputy mayor in charge of "gender equality and the fight against discrimination". Yet, two years later, when the plan for applying for the label was officially launched, the project was transferred to another deputy mayor in charge of "human resources and the modernization of public services". Simultaneously a "diversity coordinator" was appointed within the HR service. The "Integration and Equality" division, responsible for implementing antidiscrimination policies, was only involved as an "observer" in the label project. Such a transfer of political and administrative jurisdiction was not without consequences for the framing of the Diversity Label: as in Nantes, it was seen as a "lever for HR professionalization and for collective performance"10 and part of a wider dynamic of managerial reform.

\section{Diversity without race}

Beyond these institutionalization and managerialization processes, the involvement of Nantes and Paris in the Diversity Label led to the deracialization of anti-discrimination policies - by which we mean the marginalization, and even the erasure, of their ethnoracial dimension. Admittedly, the label itself, reflecting the multi-ground framework of French anti-discrimination law, hardly encouraged candidate organizations to tackle the ethno-racial issue head-on. However, the Diversity Label could have been interpreted in a singular manner by local governments already engaged in fighting against racial discrimination. 
In Nantes, the rise of ethno-racial concerns began in the early 2000s. As in other large French cities at the time (Meziani-Remichi and Maussen 2017), the urban policy department took steps to ensure access to municipal jobs for the descendants of immigrants living in disadvantaged neighbourhoods. In particular, they took the opportunity of the "emplois jeunes" -a national program that subsidized employers willing to hire young people alienated from employment- to press the Nantes administration for recruiting young people of foreign descent living in the most deprived neighbourhoods. These initiatives, under condition that they were not explicitly based on ethno-racial categories, enjoyed the support of the city council. But it was not until the suburban riots of November 2005 that the fight against ethno-racial discrimination in municipal employment was explicitly put on the political agenda. Three months after the riots, on the mayor's initiative, Nantes co-sponsored a forum entitled "Diversity in employment: what commitments and what means to fight discrimination based on people's descent?" in the presence of the deputy minister responsible for promoting equal opportunities (égalité des chances), Azouz Begag. In the aftermath of the event, Nantes adopted a "diversity and gender balance" (diversité et mixité) action plan, promoting anti-discrimination principles within the Nantes administration. Yet, the implementation of anti-discrimination initiatives encountered resistance from HR officers. The latter mostly expressed a strong loyalty to the colour-blind competitive examination (concours, a standardized professional entrance examination), which they thought guaranteed full "republican equality" in the selection process for public administration jobs.

I remember a fierce battle we had with HR after the opening of a new pool. We told the Deputy Mayor in charge of personnel that it was unthinkable not to do neighbourhood 
recruiting. He fully agreed. Yet, on the HR side, we hit a deadlock. Public entrance examinations are an equalizer, they said. Why would we be giving preference to the neighborhood inhabitants? (Municipal officer)

By the time Nantes applied for the Diversity Label a decade later, the new HR leadership had rallied to the cause of antidiscrimination. Yet, the seizure of anti-discrimination issues by the HR department favoured the rise of a formal, colour-blind approach to equality. The Diversity Label officer, who reported to the head of HR, self-identified as a HR professional rather than as an anti-discrimination specialist. She expressed her willingness to break with the "activist" approach and with the focus on ethno-racial issues that had characterized the city officers previously in charge of anti-discrimination issues. In line with the HR leadership's managerial vision of the Diversity Label, she envisioned it as a tool aimed at guaranteeing the principle of equal treatment between individuals, rather than as a means to redress structural inequalities between majority and minority groups. The marginalization of ethno-racial concerns in Nantes was also the result of the growing weight of other domains of the municipal equality policy. Beyond the rise of formal equality principles in HR procedures, applying for the label favoured, in Nantes, the development of initiatives specifically aimed at gender equality and the integration of disabled workers. These two components of the diversity policy corresponded to category-based national policies that were more prescriptive and could be monitored with indicators ${ }^{11}$, unlike the ethno-racial component.

In Paris, the involvement in the Diversity Label was associated to a similar deracialization of the local anti-discrimination policy. The label's specifications require candidate employers to carry out an internal diagnostic procedure. This initial diagnosis aims at 
identifying the "risks of discrimination in their various activities" (recruitment, promotion, remuneration, training, communication, relations with suppliers, etc.), and allows for determining what aspects will be prioritized in the diversity policy ${ }^{12}$. In Paris, the "risk evaluation table" designed by a specialized consultant hired by the HR department listed the discrimination grounds on which the city needed to focus to prepare its application for the Diversity Label: age, gender, sexual orientation, disability, union membership, and place of residence.

Interestingly, the "descent" (origine) criterion was not included in the list of the "main discrimination risks". Asked about this absence, the diversity officer mentioned the internal resistance to the recognition of racism and ethno-racial discrimination as an organizational issue.

- Are there things that came up from the audit on issues of racism?

- No. Some people would say: "it seems to me that I didn't get such-and-such a job because I am black or whatever". These are just impressions, which maybe aren't fully accurate? Anyway there is no means to measure this. And then, really, the principle of equality in public recruitment masks the issue. The argument that cannot be fought is: “Well, the public recruitment exams are open to everyone. If they don't pass the exams, they can't be selected".

Unlike her counterpart in Nantes, this diversity officer demonstrated particular concern with ethno-racial discrimination, an issue she had dealt with in a previous job. However, even for this officer, the issue seemed to be both "taboo" within the city administration and in the realm of subjective "impressions", and therefore difficult to objectify and deal with. In accordance with the internal diagnosis, the action plan set up by the city of Paris to apply for the Diversity Label focused on three discrimination grounds: disability, sex and age. Like in Nantes, priority was given to disadvantaged groups that, unlike ethnic minorities, are the target of proactive public policies that can be informed by statistical indicators. 


\section{The unlikely ethno-racial marking of French local anti-discrimination policies: the contrasting case of the Seine-Saint-Denis department}

In the Seine-Saint-Denis department, which has a particularly high proportion of ethnoracial minorities in its population compared with the rest of France, the effects of the Diversity Label differed from those observed in Paris and Nantes in two respects: first, the label was used as a lever to build a comprehensive anti-discrimination policy, both with internal and external components and second, it did not lead to the fading away of the ethno-racial aspect of anti-discrimination policy.

In his inaugural speech after his election in 2015, the socialist president of the Seine-SaintDenis department announced that fighting against discrimination would constitute a priority of his mandate, which was to be achieved by obtaining the Diversity Label. An "Equality and Diversity" unit was then set up to prepare the application for the label, which was obtained in 2016. This office was attached to a renewed "Management, Human Resources, and Diversity" Division, one of the main divisions of the HRD. However, unlike in Paris and Nantes, this attachment to the HRD did not lead to a separation between the internal and external components of the anti-discrimination policy. As the Equality and Diversity officer put it during an interview, even though the label "deals with the internal", it "provides a framework for accustoming [the department's bureaucracy] to the issue of the fight against discrimination". A year after being awarded the label, the Equality and Diversity office produced a "departmental plan for fighting discrimination" based on an "overall diagnosis of discrimination across the entire territory", with the aim of making 
local public services "exemplary". In other words, the Diversity Label acted in the SeineSaint-Denis department as a lever for putting anti-discrimination policies on the agenda, and deploying them both internally and externally.

Moreover, the Seine-Saint-Denis department contrasts with the two other cases studied because of the importance given to the ethno-racial dimension of discrimination. Admittedly, the Diversity Label had, in some respects, a deracializing effect on antidiscrimination policies, as it was the case in the cities of Paris and Nantes. The "diagnosis of the risks of discrimination" made by a specialized consultant as part of the application for the label highlighted the fact that, among the 37 per cent of city officers who said they had been "witnesses or victims of discrimination", "descent" was the first ground cited. ${ }^{13}$ Yet the five "action plans according to specific grounds based on the identification of risks"14 drawn up by the Equality and Diversity unit on the basis of this diagnosis focused on sex, (real or presumed) religious affiliation, disability, state of health, and age; none concerned descent. When asked about the disappearance of this criterion, the Equality and Diversity officer argued that discrimination based on descent was a "strong feeling" among employees, "but not a management risk". In her narrative, the experience of ethno-racial discrimination was a problem of "racism between colleagues", an issue that, she said, "is not part of the discrimination risks" assessed in the process of the application for the Diversity Label. In her view, the problem of ethno-racial discrimination was an interpersonal problem rather than a matter of HR management processes. This justified not making such discrimination ground the subject of a dedicated "action plan" within the framework of the label. 
Nevertheless, ethno-racial concerns were still much more explicit in the Seine-Saint-Denis department than in the cities of Nantes and Paris. Relying on the results of the diagnosis carried out for applying to the Diversity Label, which were confirmed by later internal inquiries, the Equality and Diversity office launched an awareness-raising program targeting employees and managers on ethno-racial discrimination, distinct from the Diversity Label action plan targeting the "risks of discrimination" in HR processes. The fight against ethno-racial discrimination appeared even more central in the anti-discrimination initiatives directed towards the territory. This was stated as a priority issue for the SeineSaint-Denis department, whose communication strategy aimed to reversing the stigma of racialization: "for the Department's President, diversity is one of the main features of the Seine-Saint-Denis", and "diversity is an asset", said the president's assistant in an interview (2018). In the department's official communications, the connection was routinely made between "diversity" and "the fight against [by implication ethno-racial] discrimination": "Although diversity is part of the richness of [the Seine-Saint-Denis], too often it is at the cost of the daily experience of discrimination by its inhabitants. The department is therefore duty bound to send out a clear signal in seeking to be exemplary as an employer," the department's diversity officer stated, in a document promoting the Diversity Label in the mid-2010s.

\section{Discussion and conclusions}

Our article shows the paradoxical effects of the Diversity Label at the subnational level: it both institutionalized and often deracialized anti-discrimination policy. In doing so, we 
contribute to the literature on diversity policies implemented by local governments in France and in other countries in several respects.

First of all, our research confirms certain findings of this literature - notably, that the composition of the coalitions in power in local governments is a major determinant of the implementation of anti-discrimination and diversity policies, as demonstrated by the quantitative study carried out by Martínez-Ariño and al. (2018) in 20 large French cities. Indeed, in 2019, 5 out of 6 local governments that have been awarded the Diversity Label are governed by centre-left and green coalitions. Moreover, the studies that we conducted in 9 other cities between 2013 and 2018 show that only authorities headed by a Socialist considered applying for the Diversity Label. Three of these, which had taken preliminary steps to do so, abandoned the plan after the defeat of the outgoing administration in the municipal elections of 2014. Interviews with a diverse range of actors confirmed the strongly politicized nature of the issue of the fight against (ethno-racial) discrimination at the local level. Yet, although centre-left local governments focused on the issue during the Sarkozy presidency, the election of a Socialist president and parliamentary majority in 2012 neither had the effect of putting it back on the national agenda, nor did it result in its disappearance from the local government agendas. Our investigation thus confirms that local governments can exercise some autonomy on diversity issues: policy orientations in this field depend on local factors (social, political and institutional) and not only on national policies.

However, our in-depth, qualitative investigation of three cases has also brought to light dimensions overlooked by studies on a more macro scale and based on quantitative 
methods. Especially, our approach made it possible to thoroughly examine local policies that fall under the umbrella term of "anti-discrimination" or "diversity", and the salience of ethno-racial issues within them. We found that the introduction of local government policies under these headings does not necessarily lead to this type of discrimination being addressed, even though these policies were initially put on the agenda to address ethnoracial discrimination. Indeed, when the issue of "fighting against discrimination" was put on the government's agenda at the end of the 1990s (Heargraves 2015), and when the term "diversity" found its way into the French business world in the mid-2000s, these terms were mostly referring to post-colonial immigrants and their descendants. The terms "diversity" and "anti-discrimination" were then euphemisms for ethno-racial issues, in a context where no legitimate vocabulary existed for referring to racial minorities. But in following years, at the national level, these terms gradually lost their ethno-racial connotations. To an increasing extent, they were used to designate the multi-ground legal framework of equal treatment and referred, in practice, to categories targeted by specific public policies such as disability and gender equality. Our investigation shows that this process of deracialization of diversity, which has been observed in other social settings (Lemercier and Palomares 2012, Doytcheva 2015, Mazouz 2017, Bereni 2020), could also be observed in local governments during the 2010s, despite an unprecedented politicization of anti-discrimination at this level. The decline of public policies targeting ethno-racial discrimination at the national level, the impossibility of collecting ethno-racial data, and the persistence of competing paradigms in policies aimed at immigrants and their descendants acted as powerful curbs on the recognition of ethno-racial discrimination as 
specific problem at the local level - including for local governments that were the most "committed" to "diversity".

Our investigation also suggests, through the analysis of the untypical case of the SeineSaint-Denis department, that the proportion of immigrants and their descendants in the population does affect the possibility for local government to address straightforwardly ethno-racial discrimination in a colour-blind country. From this point of view, our study leads to temper the results of the quantitative investigation by Martínez-Ariño and al. (2018), which found that the proportion of foreign-born people has no effect, in France (in contrast to Germany, where it is the determinant variable), on the implementation of diversity policies. We find that the especially significant over-representation of ethno-racial minorities and the racial stigma attached to this suburban department seem to constitute a safeguard against the dynamic of deracialization of anti-discrimination policies observed in other local governments and at the national level.

Finally, our investigation is an invitation to closely examine the contextualized meanings of "diversity". This term refers to different realities in different contexts, and its meaning is flexible and ambivalent in a given context (Raco and Tasan-Kok 2019). It routinely refers simultaneously to differences founded on ethno-racial grounds and to "all individual differences", thereby diluting the ethno-racial dimension - and this even in contexts where ethno-racial issues are the core targets of public policies, as demonstrated by research on diversity management in the United States (Edelman 2016, Kelly and Dobbin 1998, Berrey 
2015). We should therefore recognize the empirical ambivalence and pliability of the category of diversity, and shift away from normative definitions.

\section{Endnotes}

${ }^{1}$ Several historical studies showed that the republican principle of colour-blindness coexisted with the use of ethno-racial categories in the colonized territories overseas (Larcher, 2014)

${ }^{2}$ https://www.charte-diversite.com/

${ }^{3}$ https://www.fonction-publique.gouv.fr/label-diversite-dans-la-fonction-publique. It should be noted that these numbers do not take into account the hundreds of - mostly private - organizations that had been granted the label in the early 2010s, but did not apply for renewal after a 4-year period.

${ }^{4}$ France has three layers of local government (collectivités territoriales): regions, departments, municipalities. In addition to that, an intermediate metropolitan layer is emerging between the local and the departmental levels in large urban areas.

5 The label was also granted to Lyon (2010), Dijon (2018), and Bordeaux (2019).

${ }^{6}$ According to French administrative categories, an immigrant (immigré) is a person who is born a foreigner and abroad, and resides in France. Thus, an immigrant is not necessarily a foreigner: in 2013, 40\% of immigrants were French (INSEE 2016). In 2008, immigrants made up 10 per cent of the population living in France, as well as people of immigrant descent (descendants d'immigrés) (Beauchemin, Hamel, Simon 2018). 52 per cent of immigrants and people of foreign descent stem from a non-EU country, most frequently from countries that used to be under French colonial rule.

7 In 2011, the High Authority for the Fight against Discrimination and for Equality (HALDE) merged into a new Administrative Independent Authority, the Défenseur des Droits.

${ }^{8}$ Workshop of the Inter-Réseau du Développement Social Urbain, 2011, « Les politiques d'égalité: concurrence des publics ou convergence des luttes ? », Poitiers, April 14-15.

${ }^{9}$ In January 2019, seven local governments were holders of the Equality label.

${ }^{10}$ Interview with the diversity coordinator of Paris, 2018.

${ }^{11}$ Since 1987 the French state has required private and public employers above a certain size to hire a quota of 6 per cent disabled individuals. Employers that do not comply must pay financial penalties, which were substantially increased by a 2005 law. Alongside this, a gender equality policy has been in place since the early 1980s; it was strengthened during the 2000s. It is based on incentives for collective bargaining, reporting obligations, and gender quotas for senior official jobs in public administration.

${ }^{12}$ AFNOR website.

${ }^{13}$ Report "Le Département et ses agents face aux discriminations" [The department and its officers faced with discrimination], September 2017.

14 Ibid. 


\section{References}

Abbott, A. 1988. The System of Professions. An Essay on the Division of Expert Labor. Chicago: University of Chicago Press.

Avanza, M. 2010. “Qui représentent les élus de la 'diversité' ? Croyances partisanes et points de vue de 'divers'." Revue française de science politique 60 (4): 745-767.

Beauchemin, C., Hamel, C., Simon, P. 2018. Trajectories and Origins: Survey on the Diversity of the French Population. Population Studies. Springer.

Bereni, L. 2009, “'Faire de la diversité une richesse pour l'entreprise'. La transformation d'une contrainte juridique en catégorie managériale." Raisons politiques 35: 87-106.

Bereni, L., and R. Epstein. 2015. "Instrumenter la lutte contre les discriminations : le "Label Diversité" dans les collectivités territoriales. Rapport final." Alliance de recherche sur les discriminations (ARDIS).

Bereni, L. 2020. "La valeur professionnelle de l'identité. Racialisation, genre et légitimité managériale à New York et à Paris." Sociétés contemporaines, forthcoming.

Bergeron, H., P. Castel, and S. Dubuisson-Quellier. 2014. " Gouverner par les labels. Une comparaison des politiques de l'obésité et de la consommation durable." Gouvernement et action publique 3 (3): 731 .

Berrey, E. 2015. The Enigma of Diversity. The Language of Race and the Limits of Racial Justice. Chicago: University of Chicago Press.

Bezes, P. 2017. "The Neo-Managerial Turn of Bureaucratic States. More Steering, More Devolution." in Reconfiguring European States in Crisis edited by King D., Le Galès P., 251278, Oxford: Oxford University Press.

Bleich, E. 2000. "Antiracism without Races: Politics and Policy in a 'Color-Blind' State". French Politics, Culture \& Society 18 (3): 48-74.

Calvès, G. 2016. La discrimination positive, Paris: PUF.

Cerrato Debenedetti, M-C. 2018. La lutte contre les discriminations ethnoraciales en France: De l'annonce à l'esquive. Rennes: PUR.

Chappe, V-A. 2011. "Le cadrage juridique, une ressource politique ? La création de la HALDE comme solution au problème de l'effectivité des normes anti-discrimination (19982005)." Politix 94: 107-130.

Dekker, R., H. Emilsson, B. Krieger, and P. Scholten. 2015. "A Local Dimension of Integration Policies? A Comparative Study of Berlin, Malmö, and Rotterdam." International Migration Review 49 (3): 633-658.

Dikec, M. 2007. Badlands of the republic: space, politics and urban policy. Oxford: Blackwell Publishing.

Dobbin, F. 2009. Inventing Equal Opportunity. Princeton: Princeton University Press. 
Downing, J. 2016. "Influences on state-society relations in France: Analysing voluntary associations and multicultural dynamism, co-option and retrenchment in Paris, Lyon and Marseille." Ethnicities 16 (3), 452-469.

Doytcheva, M. 2015. Politiques de la diversité. Sociologie des discriminations et des politiques antidiscriminatoires au travail. Bernes: Peter Lang.

Edelman, L. 2016. Working Law: Courts, Corporations, and Symbolic Civil Rights, Chicago and London: University of Chicago Press.

Epstein, R. 2013. La rénovation urbaine : démolition-reconstruction de l'Etat, Paris :Presses de Sciences Po.

Escafré-Dublet A., Lelévrier C. 2019. "Governing diversity without naming it: An analysis of neighbourhood policies in Paris." European Urban and Regional Studies 26(3): 283-296.

Favell, A. 1998. Philosophies of Integration: Immigration and the Idea of Citizenship in France and Britain. London: St. Martin's Press.

Fassin, D., Fassin, E. (eds). 2006. De la question sociale à la question raciale ? Représenter la société française Paris: La Découverte.

Flamant, A. 2017. "L'incomplète construction des politiques municipales de lutte contre les discriminations raciales. Enquête dans les villes de Lyon, Nantes et Strasbourg (20012012)." Revue internationale de politique comparée 24 (3): 257-292.

Heargraves, A. 2015. "Empty Promises? Public Policy Against Racial and Ethnic Discrimination in France." French Politics, Culture \& Society 33 (3): 95115.

INSEE. 2016. France, Portrait Social, Paris: INSEE Editions.

Kelly, E., Dobbin, F. 1998. "How Affirmative Action Became Diversity Management : Employer Response to Anti-discrimination Law, 1961 to 1996." American Behavioral Scientist 41 (7): 960-984.

Kirszbaum, T. 2004. "La discrimination positive territoriale : de l'égalité des chances à la mixité urbaine." Pouvoirs 111: 101-118.

Lamont, M., A. Morning, and M. Mooney. 2002. "North African Immigrants Respond to French Racism: Demonstrating Equivalence through Universalism." Ethnic and Racial Studies 25: 390-414.

Larcher, S. 2014. L'autre citoyen : l'idéal républicain et les Antilles après l'esclavage. Paris: Armand Colin.

Lemercier, E., and E. Palomares. 2012. "La disparition. Le traitement de la 'question raciale' dans l'action publique locale de lutte contre les discriminations." Revue Asylon(s), 8.

Le Galès, P. 2011. Le retour des villes européennes. Sociétés urbaines, mondialisation, gouvernement et gouvernance. Paris: Presses de Sciences Po. 
Martínez-Ariño, J., M. Moutselos, K. Schönwälder, C. Jacobs, M. Schiller, and A. Tandé. 2018. "Why do some cities adopt more diversity policies than others? A study in France and Germany." Comparative European Politics 17 (5): 651-672.

Mazouz, S. 2017. La République et ses Autres. Politiques de l'altérité dans la France des années 2000. Lyon: Ens Lyon.

Meziani-Remichi, Y., and M. Maussen. 2017. "Recruitment in public administrations: diversity policies and selection practices in a French city." Journal of Ethnic and Migration Studies 43 (10): 1679-1695.

Peer, S., and D. Sabbagh. 2008. "French Color-Blindness in Perspective: The Controversy over 'Statistiques Ethniques' (Special Issue)." French Politics, Culture and Society 26 (1): 16.

Poppelaars, C., and P. Scholten. 2008. "Two Worlds Apart: The Divergence of National and Local Immigrant Integration Policies in the Netherlands." Administration \& Society 40(4): 335-57.

Raco, M., and T. Tasan-Kok. 2019. "Governing urban diversity: Multi-scalar representations, local contexts, dissonant narratives." European Urban and Regional Studies, 26(3), 230-238.

Safi, M. 2017. "Promoting Diversity in French Workplaces: Targeting and Signaling Ethnoracial Origin in a Colorblind Context." Socius 3:1-14.

Schiller, Maria. 2015. "Paradigmatic pragmatism and the politics of diversity." Ethnic and Racial Studies 38(7): 1120-36.

Schnapper, D. 1998. Community of Citizens: On the Modern Idea of Nationality. New Brunswick, N.J: Transaction Publishers.

Simon, P. 2008. "The Choice of Ignorance: The Debate on Ethnic and Racial Statistics in France." French Politics, Culture, \& Society 26 (1): 7-31.

Simon, P. 2015. "La lutte contre les discriminations n'a pas eu lieu." Mouvements, (83): 8796.

Sala Pala, V. 2010. "Differentialist and Universalist Anti-Discrimination Policies on the Ground: How Far they succeed, Why they Fail. A comparison between Britain and France" American Behavioral Scientist 53 (12):1788-1805.

Stryker, Robin. 2001. "Disparate Impact and the Quota Debate: Law, Labor Market Sociology, and Equal Employment Policies." The Sociological Quarterly 1 (42): 13-46.

\section{Funding}

This work was supported by the Alliance de recherche sur les discriminations (ARDIS) 